\title{
Bacterial Urinary Tract Infection among Adult Renal Transplant Recipients at St. Paul's Hospital Millennium Medical College, Addis Ababa, Ethiopia
}

\author{
Teklehaimanot kiros ( $\nabla$ tk30j@gmail.com ) \\ Debre Tabor University \\ Daniel Asrat \\ Addis Ababa University \\ Zeleke Ayenew \\ Ethiopian Public health institute \\ Estifanos Tsige \\ Ethiopian Public health Institute
}

\section{Research article}

Keywords: Kidney Transplantation, Urinary Tract Infection, Antimicrobial Susceptibility Testing, St. Paul's Hospital Millennium Medical College, Addis Ababa, Ethiopia

Posted Date: July 1st, 2019

DOl: https://doi.org/10.21203/rs.2.10826/v1

License: @ (1) This work is licensed under a Creative Commons Attribution 4.0 International License. Read Full License

Version of Record: A version of this preprint was published at BMC Nephrology on July 31st, 2019. See the published version at https://doi.org/10.1186/s12882-019-1485-9. 


\section{Abstract}

Abstract Background: Despite significant advances in surgical techniques, immunosuppression protocols follow up periods and antimicrobial stewardship in modern medicine; post-renal transplantation urinary tract infection remained a major public health problem globally. This multiple serious squeal includes asymptomatic bacteriuria, cystitis and pyelonephritis. Among these, the bacterial origin of infection complications accounts for the most significant clinical, socio-economic impacts in many countries of the world. Therefore, the aim of the study was to investigate the prevalence of bacterial isolates that cause urinary tract infections, assess antibiotic susceptibility pattern among symptomatic and asymptomatic renal transplant recipients attending at St. Paul's Hospital Millennium Medical College, Addis Ababa, Ethiopia. Methods: A hospital-based cross-sectional study was conducted from December 2017 to August 2018 among 74 renal transplant recipients St. Paul's Hospital Millennium Medical College, Addis Ababa, Ethiopia. A first morning voided clean-catch mid-stream urine specimens were collected and $0.001 \mathrm{ml}$ inoculated onto blood and MacConkey agar plates following the standard bacteriological protocols. It was incubated aerobically at $35-37^{\circ} \mathrm{C}$ for $24-48$ hours. Cultural characteristics and series of biochemical tests were used for the identification of isolates to species level. Results: Significant bacteriuria was found in $11 / 74(14.9 \%, 95 \% \mathrm{Cl}=8.2-24.7)$ patients. The prevalence among females $6 / 32(18.75 \%)$ was higher among males $5 / 42(11.9 \%)$ without significant association ( $C O R=2.09,95 \% \mathrm{Cl}=1.04-8.45, \mathrm{P}=0.253)$. Urinary tract infection was higher in the age group of 35-49 years old (19.3\%). Age was statistically significant and stronger independent associated risk factor with crude odds ratio=3.67, 95\% $\mathrm{Cl}=2.89-20.07$ and $P=0.003$, respectively. The most prevalent bacteria isolates were Escherichia coli 2(18.2\%), Staphylococcus aureus 2(18.2\%), Acinetobacter spp. 2(18.2\%), Enterococcus spp. 2(18.2\%), Coagulase-negative Staphylococci 2(18.2\%) followed by Portus mirabilis $1(9.1 \%)$. The majority ( $80 \%)$ of Gram-negative bacteria were resistant to ciprofloxacin, chloramphenicol, and trimethoprim/sulfamethoxazole. Conclusions: In conclusion, the overall prevalence of urinary tract infection in the study participants was relatively low with a prevalence of $14.9 \%$. Majority of the study participants were asymptomatic. The multidrug-resistant bacterial isolates in the present study account for $82 \%$. Keywords: Kidney Transplantation, Urinary Tract Infection, Antimicrobial Susceptibility Testing, St. Paul's Hospital Millennium Medical College, Addis Ababa, Ethiopia.

\section{Background}

The urinary tract is protected against infections by several mechanisms unlike the kidney transplant patients are vulnerable to multiple infections like bacterial, viral, fungal and parasitic infections. Despite significant advances in surgical techniques, immunosuppression protocols and study designs; post-renal transplantation urinary tract infections particularly the bacterial origin continues to be a major public health problem globally with significant morbidity and mortality [1].

Post-renal transplantation urinary tract infections squeal including asymptomatic bacteriuria, cystitis, and pyelonephritis are the most common form of bacterial infection following renal transplantation. It could result in allograft graft loss, allograft function impairment and even death. These can occur at any time but with the highest incidence observed in the first 3-6 months after transplantation [2].

During the first month, asymptomatic bacteriuria is the most common phenomena regardless of the proven guidelines are lacking for both diagnosis and treatment in the global community. The globally reported prevalence of post- renal transplantation urinary tract infection may vary depending on several factors and conditions such the study design, selection of antimicrobial prophylaxis and lack of advanced diagnostic facility to track post-renal transplantation urinary tract infection. Hence, many authors described that it ranged from $4 \%$ to $75 \%$ [3]. Likewise, the overall incidence of UTI in solid organ transplant recipients was reported 0.23 episodes/1000 days of transplant. However, this incidence varies significantly depending on the type of transplanted organ being the renal transplants are the highest risk groups among any other organ transplants. In this case, infections develop more rapidly among renal transplants than any other organ transplant so that rigorous post-renal infection intervention strategies are highly demanded to diminish any grave impacts $[4,5]$.

In many countries of the world, kidneys are the most frequently transplanted organs to resolve end-stage renal disease including our country Ethiopia. However, post-renal transplantation urinary tract infection has remained the leading cause of significant morbidity, mortality and graft failure, which reported globally. The discrepancies in diagnostic criteria like frequency of routine urine culture testing, uneven follow-up times as wee as the lack of rigorous center infection prevention and control strategies enhance these multiple squeals to disseminate globally. These clinical and socio-economic impacts are relatively higher in developing countries mainly due to the low availability of resources required for early screening and treatment of infections [6, 7]. Renal transplants are more prone to infections than non-transplanted population. The superimposed immune suppressions aimed to maintain the acute or chronic allograft rejection triggers antimicrobial selective pressure especially to the Gram-negative bacilli $[8,9]$. In general, speaking bacterial species leading to 
urinary tract infection in renal transplant recipients are similar to those causing UTIs in the general population. However, an influence of early intensive immunosuppression regimens and antimicrobial prophylaxis particularly at the post-operative procedure promotes drug susceptible and less virulent strains to cause infection in renal transplants unlike in the general population. As a result, management in renal transplant recipients is undoubtedly more complex compared with the general population. Several factors may contribute to kidney allograft loss and grave outcome impacts. These include anatomical factors, surgical factors, microbial factors and allograft factors [3, 10-14].

\section{Methods}

\section{Study design, area and period}

A hospital-based cross-sectional study was conducted between December 2017 and August 2018. The study was conducted at St. Paul's Hospital Millennium Medical College at the National Kidney Transplantation Center.

\section{Study population}

The study population were all adult kidney recipients aged $\geq 18$ years who came for their check-up to the renal transplantation center suspected for both asymptomatic, symptomatic bacteriuria and who did not initiate of antibiotics therapy during the last two weeks and during data collection.

\section{Sample collection and processing}

\section{Sample collection}

Seventy-four early morning $5 \mathrm{ml}$ of midstream urine specimens were collected from all kidney recipients using wide-mouthed, sterile, leak-proof re-usable plastic containers following standard bacteriological procedures. All of the specimens were analyzed within an hour of collection. All relevant data concerning socio-demographic characteristics, related risk factors to UTI, clinical signs and symptoms of the study participants were obtained using pre-designed structured questionnaires.

\section{Bacterial culture and identifications}

Relevant data on the etiological agents were obtained using standard microbiological laboratory tests. The laboratory procedures were performed at clinical Bacteriology and Mycology laboratory located at National Reference Laboratory of the Ethiopian Public Health Institute, Addis Ababa, Ethiopia. All the laboratory procedures were performed using standard bacteriological procedures. Briefly, using calibrated wire loop One $\mu \mathrm{l}(0.001 \mathrm{ml})$ clean-catch midstream urine samples were inoculated into MacConkey (MAC) and $5 \%$ sheep blood agar plate (BAP) (Oxoid, UK). Then, cultures were incubated in the aerobic atmosphere at $35-37^{\circ} \mathrm{C}$ for $24-48$ hours. Colonies were counted to check the presence of significant bacteriuria. Colony count yielding bacterial growth of $\geq 10^{5} \mathrm{cfu} / \mathrm{ml}$ of urine was considered significant bacteriuria according to the Infectious Diseases Society of America (IDSA) guidelines [15]. All positive cultures with significant bacteriuria were then subjected to test identification to species level by their colony characteristics and patterns of biochemical profiles using standard bacteriological procedures. The Gram-negative bacteria (Enterobacteriaceae) were identified by indole production, $\mathrm{H} 2 \mathrm{~S}$ production, lactose fermentation in triple sugar iron agar, citrate utilization, motility test, urease test, bile solubility, utilization of lysine in lysine decarboxylase agar. Oxidase test was also performed for non-fermenter Gram-negative rods. The Gram-positive bacteria were identified using routine bench tests such as catalase, coagulase and bile-esculin tests $[3,16]$.

\section{Antimicrobial susceptibility testing}

The antimicrobial susceptibility testing for every significant isolate was performed by adhering to the standard bacteriological procedures. Appropriate selection of antimicrobial agents was made based on the frequent prescription of antimicrobial agents in the study area, local market availability, expert opinion in conjunction to the criteria of the Clinical and Laboratory Standards Institute (CLSI) for the treatment of urinary tract infection. Mueller-Hinton agar (Oxoid, UK) was used to do the susceptibility testing for the isolated 
bacteria. In brief, from a pure culture, a loopful of bacterial colonies was taken and subjected to a tube containing $5 \mathrm{ml}$ of normal saline. The final preparation was mixed gently until it forms homogenous suspension thought of the tube. To assured with standard inoculum size for testing and resolve any associated errors during antimicrobial susceptibility testing, the turbidity of an even suspension was adjusted to the density of McFarland $0.5 \mathrm{~g}$ aseptically. Subsequently, a bacterial suspension was picked-up via a sterile cotton swab and gently rotated over the surface of the Mueller-Hinton agar at least three times including the rim of the agar plate adhering to the manufacturer's instruction to do susceptibility test [16]. Caution was taken to avoid any exposure to air bubbles including any excess suspensions during the procedure that could grossly alter the result and report. To avoid any excess moistures at any surfaces of the agar plate, which hastens diffusivity of antimicrobial agents, inoculated plates were left at room temperature to dry for 3-5 minutes. Then, antimicrobial agents were brought to the room temperature and placed over the working table. Using a sterile forceps, the antibiotic disc was put on the surface the agar plate at the reasonable diameter and a slight pressure was applied to ensure proper contact of the discs with agar plate. Finally, the plates were incubated at $35^{\circ} \mathrm{C}-37^{\circ} \mathrm{C}$ for $24-48$ hours and then the isolates were typed susceptible, intermediate and resistant based on diameters of the zone of inhibition around the discs against the criteria of Clinical and Laboratory Standards Institute,2018[17].

\section{Quality control}

The quality of culture media was tested for sterility and performance. Sterility of culture media was checked by incubating overnight at $35-37^{\circ} \mathrm{C}$ without specimen inoculation. Standard reference strains of E. coli (ATCC 25922), S. aureus (ATCC 25923) and P. aeruginosa (ATCC 27853) were used for quality control throughout the study for culture and antimicrobial susceptibility test.

\section{Data management and analysis}

All the patient's records were anonymized by giving a number to each sample and questionnaire before the analysis and secured at all levels. All data were analyzed taking due to care for completeness, consistency, coding and sorting using SPSS (Statistical Package for Social Sciences) computer program (Version 20.0). Then, tables and texts were utilized to explain the descriptive data. In all cases, Pvalue $<0.05$ was taken as statistically significant. Furthermore, to assess any associated risk factors for post-renal transplant UTI, bivariate and multivariate logistic regression risk factor analysis was done to calculate crude/adjusted odds ratio and $95 \%$ confidence interval.

\section{Ethical Considerations}

Ethical approval was obtained from the Department Ethics Research Committee(DERC), Department of Microbiology, Immunology, and Parasitology, School of Medicine, College of Health Sciences, Addis Ababa University (DERC committee's reference number: DERC/17/18/02-C). Subsequently, ethical approval was also obtained from St. Paul's Hospital Millennium Medical College (SPHMMC) Institutional Review Board (IRB reference number: P.m 23/409). Finally, the study secures at all levels and study participants were informed about the objective and benefit preceding the data collection procedure.

\section{Results}

\section{Socio-demographic characteristics of studied participants}

A total of 74 study participants ( 38 with symptoms and signs of UTI and 36 without symptoms and signs of UTI) were included in the study at St. Paul's Hospital Millennium Medical College. A majority, 42/74(56.8\%) of them were males. The mean age was 41.55 years old with a standard deviation of $11.33(41.55 \pm 11.33)$ and a median of 40.5 . Bacteriuric males were much younger than bacteriuric females (19 and 25 years old) respectively.

Majority of the study participants $31(41.9 \%)$ were within the age group of $35-49$ followed by $18-34(29 / 74,39.2 \%)$. While the marital status indicated that $40.5 \%$ were married. Significant bacterial UTI was diagnosed in $11 / 74(14.9 \%, 95 \% \mathrm{Cl}=8.2-24.7)$. Bivariate logistic regression to assess the associated risk factors with post-transplantation UTI has shown no significant association except to age with crude odds ratio $=3.67,95 \% \mathrm{Cl}=2.89-20.07, \mathrm{P}=0.003$ (Table1). 
Table 1: Sociodemographic characteristics of study participants with and without UTI, St Paul's Hospital Millennium medical college, Addis Ababa, Ethiopia.

\section{Clinical characteristics of study participants}

The average time since transplantation in months was $38.4 \pm 4.8$ (Table 2).

Table 2: Prevalence of UTI in related clinical variables of renal transplants recipients.

\section{Prevalence of significant bacteriuria among renal transplant recipients}

In the present study, significant bacteriuria was detected in 11/74 (14.9\%) of the study participants investigated for urinary tract infection. In the meantime, the magnitude of significant bacteriuria has shown no association with the clinical signs and symptoms for post-renal transplantation urinary tract infection (Table 3). E.coli, P.mirabilis and Acinetobacter spp. were exclusively found in asymptomatic patients (Table 4).

Table 3: Significant bacteriuria from urine culture of renal transplant recipients

Table 4: Bacterial species isolated from asymptomatic and symptomatic UTI among renal transplant recipients, St Paul's Hospital Millennium medical college, Addis Ababa, Ethiopia.

\section{Bacterial etiologies}

A total of 11 bacteria were isolated (Table 5), out of these, 5 (45.4\%) were Gram-negative bacteria and 6 (54.6\%) were Gram-positive bacteria (P-value $=0.741)$. The magnitude of early UTI $(n=17$ patients, 3 isolates) varies significantly from late UTI occurring $>6$ months postoperative period ( $n=57$ patients, 8 isolates).

Table 5: Bacterial etiologic agents isolated from urine culture of renal transplants

\section{Antibiotic susceptibility data}

\section{Gram-positive bacteria}

Coagulase-Negative Staphylococci (CoNS) and S. aureus were highly sensitive to clindamycin (100\%). Clindamycin was the most effective antibiotic (67\%) among the tested groups (Table 6).

Table 6: Antibacterial susceptibility patterns of Gram-positive bacterial isolates.

\section{Gram-negative bacteria}

The most effective antibiotics against E.coli isolates were gentamycin (100\%). The least effective antibiotics against E.coli were ciprofloxacin, trimethoprim/sulfamethoxazole. Gentamicin was the most effective antibiotic among the groups (100\%) against the Gram-negative bacteria (Table 7).

Table 7: Antibacterial susceptibility patterns of Gram-negative bacteria isolates.

\section{Multidrug resistance patterns of bacteria isolated from renal allografts}

In the present study, Multidrug resistance (MDR = resistance in $\geq 3$ drugs) was seen in $82 \%$ of the isolates among diagnosed renal transplant recipients (Table 8).

Table 8: Multidrug resistance patterns of bacteria isolated from renal allografts. 


\section{Risk factors associated with Post -renal transplantation UTI}

Multivariate regression analysis with post-renal transplantation UTI is schemed in (Table 9).

Table 9: Multivariate risk factor analysis among post renal transplantation UTI.

\section{Discussion}

Urinary tract infections mainly the bacterial origin are the most common infectious complication that has been remained the major concern of the global health community especially to kidney transplant recipients $[18,19]$. Both formidable and none formidable associated risk factors are the leading consequences to either the allograft survival or patient survival besides the socioeconomic burdens. The influence of immunosuppression that leaves the patient immune quell is top priority [20-22].

The present study revealed that the majority (56.8\%) of study participants were males. However, a substantially higher number of females were affected by post renal transplantation UTI than males ( $18.75 \%$ versus $11.9 \%$ respectively) with no statistical significance association (crude odds ratio $=2.09,95 \% \mathrm{Cl}=1.04-8.45$ and $\mathrm{P}=0.253$ ). In harmony to the present study, a research paper by Kotagiri et al., [23] in Australia, Shams et al.,[24] in Iran and Bispo et al.,[25] in Portugal has shown that a large number of females were affected $(P=0.002, P<0.001, P<0.005$ respectively). Unlike to the present finding, study from Yemen by Gondos et al., [14], Portugal by Bispo et al.,[25] and Saudi Arabia by Alkatheri,[26] higher female prevalence of UTI (female $40.3 \%$, males $29 \%$, female $68 \%$, male $23 \%$ and female $69.2 \%$, male $30.8 \%$ respectively) were reported with no statistically significant association. This may be due to women are more susceptible to UTIs, which results from anatomical, hormonal, immunological and behavioural features [27, 28].

In the present investigation, the rate of UTI incidence was higher in the age group of 35-49 years old (19.3\%) comparing the younger age groups ( $P=0.003$, COR and $95 \% \mathrm{Cl}=3.67,2.89-20.07$ respectively). This is relatively in line with Gondos et al., [14] in Yemen that UTI was higher in the age group between $41-50$ years $(28 \%, P=0.010)$ but, inconsistency with Chuang et al., [11] has shown that patients at 65 years or older developed post-transplant UTI with $55 \%$ compared to younger patients ( $38 \%$ of patients at $<30$ years old). The possible explanation for this disparity may be probably associated with the reason that older patients may be at higher risk due to inefficient voiding because of poor bladder contractility or outflow obstruction. Impaired cellular immunity and immunosuppression tolerance are causes of old patients susceptibility to several infections [29, 30].

In the present study, the overall bacterial UTI was found $14.9 \%$ of the patients ( $95 \% \mathrm{Cl}=8.2-24.7)$. The present prevalence was quite smaller than the recent reports from different parts of the world. Shams et al.,[24] in Iran , Becerra et al.,[29] in the USA, Menegueti et al., [31] in Brazil, Elkehili et al.,[32] in Libya and Ooms et al.,[33] in Netherland reported as $22.7 \%, 28 \%, 26.2 \%, 29.5 \%$ and $28 \%$, respectively. Not surprisingly, the highest incidence of UTI among renal transplant recipients was also reported by Khosravi et al., [7] in Iran, Gondos et al.,[14] in Yemen, Alkatheri,[26] in Saudi Arabia that was $33.56 \%, 33.5 \%$ and 55.5\% respectively. However, the current result was nearly similar to reported results from Portugal (16.5\%) by Bispo et al., [25] but much higher than the report by Kotagiri et al.,[23] in Australia

$(8 \%)$. This significant variation in UTI reported rates might be due to local ascribe of outbreaks, center-specific potent immunosuppressive therapy and lack the robust definition of UTI in many clinical settings [34].

In the present study, the multivariate logistic regression has shown that $35-49$ age groups $(P=<0.001$, adjusted odds ratio $=2.61,95 \% \mathrm{Cl}$ $=2.06-18.19)$, the previous history of pre-transplantation UTI $(P=0.02$, adjusted odds ratio $=3.48,95 \% \mathrm{Cl}=2.12-9.38)$ and the previous history of catheterization ( $\mathrm{P}=0.003$, adjusted odds ratio $=3.29,95 \% \mathrm{Cl}=2.05-11.85$ ) were associated risk factor. Discordant to the present finding, Ooms et al., [33] unveiled that older age groups (>65 years old) were the risk factors for post renal transplantation UTI $(P=<0.001, A O R=3.58,95 \% \mathrm{Cl}=2.16-5.91)$.

This mismatch may be due to study design on one side and the impact of potent immunosuppressive drugs, empirical antimicrobial prophylaxes on the other sides that altogether fosters antimicrobial selective pressure. In line to the present report Bispo et al., [25] and Kumar et al.,[30] have shown the presence of pre-transplant UTI history as a risk factor for post-transplant UTI. Prompt catheter removal or replacement has been associated with a drop in UTI rates [35, 36].

In the contemporary study, the most prevalent bacteria isolates causing post-renal transplant UTI were Escherichia coli (18.18\%), Acinetobacter spp.(18.18\%), P. mirabilis (9.1\%), S. aureus (18.18\%), Enterococcus spp. (18.18\%), Coagulase-negative Staphylococci (18.18\%). This result is incomparable with recently published research paper by Gozdowska et al., [1]); E.coli (42\%) and Enterococcus spp. (10\%). Similarly, the current finding dissimilar to a retrospective study done by Kotagiri et al.,[23] that found E.coli (32\%) and 
Enterococcus spp.(35\%) which were responsible for post- renal transplantation UTI. In addition, another study unveils that E. coli (46\%), P. mirabilis (26\%), S. aureus (25.8\%) and Coagulase-negative Staphylococci $(6.8 \%)$ were etiologies of post-renal transplantation UTI which were relatively higher than the present result except to Coagulase-negative Staphylococci $[37,38]$.

The present finding was discordant with Elkehili et al.,[32] that ciprofloxacin (51.6\%), followed by amoxicillin-clavulanic acid (22.6) were choices of the drug for treating the Gram-negative. Similar to the present results, Ooms et al.,[33] noticed that $24 \%$ of tested

Enterobacteriaceae were resistant to ciprofloxacin and $86 \%$ to trimethoprim/sulfamethoxazole were not effective. This could be justified by bacterial antibiotic prophylaxis selection should have adhered to conventional urinary culture so that prophylaxis should be tailored based on appropriate antibiogram batteries. Gondos et al.,[14] in Yemen have shown that ciprofloxacin was the most effective antibiotic against Gram-positive cocci. These disparities with present findings may be due to the lack of access or local market availability of antibiotics like nalidixic acid and ampicillin were not tested in our center in the present study. Any discrepancy toward susceptibility results and different isolates varied depending on the study area, design, selection of antimicrobial agents and antibiotic stewardship program [14, 39-41].

The grave impact of post-renal transplantation urinary tract infection caused by multidrug-resistant bacterial isolates is becoming a great concern in kidney recipients. However, this growing threat to transplant population is in its infancy to the researcher community [42].

In the present study, multidrug-resistant strains were seen in $82 \%$ of the isolated bacteria. This is similar to the current study done by Yuan et al., [39] in China, which claimed that $86.4 \%$ of the tested organisms were multidrug-resistant. Gozdowska et al.,[1] and Bodro et al., [41] were reported much lower than our finding(37\%). Kotagiri et al., [23] from Australia and Adamska et al., [43] from Poland reported relatively much smaller ( $37 \%$ and $47 \%$ respectively) than the present finding. The disparity in the present study might be due to potent immunosuppression protocols and selective antibiotic pressure that cumulatively enhance the emergence of antibiotic-resistant strains. This is a threat to kidney transplants because it increases health care costs, prolongs hospital stays, can result in treatment failure, increased morbidity and mortality [44-50].

\section{Conclusion}

In conclusion, the overall prevalence of UTI in our population was relatively low with a prevalence of $14.9 \%$. Majority of the UTIs were asymptomatic. A higher percentage of females were involved. Intensive longitudinal research activities to identify the risk factors as well as to elucidate the existing controversies of post-renal-transplantation UTI over allograft outcome are highly demanding.

In countries like Ethiopia where the resources are limited especially of advanced diagnostic facilities to screen and monitor renal transplants, it is better to establish routine urine cultures especially in the first 6-12 months after kidney transplantation for recipients on follow up. The current study is indicating of the evolution of multidrug-resistant isolates among kidney transplants. To endorse judicious treatment, careful and systemic selection of antimicrobial agents together with rigorous infection preventions and control strategies should be employed to mitigate both hospital and community-acquired Urinary tract infections.

\section{List Of Abbreviations}

Not applicable

\section{Declarations}

\section{Ethics approval and consent to participate}

Ethical approval was obtained from the Department Ethics Research Committee(DERC), Department of Microbiology, Immunology, and Parasitology, School of Medicine, College of Health Sciences, Addis Ababa University (DERC committee's reference number: DERC/17/18/02-C). Subsequently, ethical approval was also obtained from St. Paul's Hospital Millennium Medical College (SPHMMC) Institutional Review Board (IRB reference number: P.m 23/409).

\section{Consent for Publication}

Not applicable 


\section{Availability of data and materials}

Data supporting the results reported in the article can be found from different datasets. The minimal dataset that would be necessary to interpret, replicate and build upon the findings reported in the article are obtained from google, PubMed and other popular search engines. The datasets used and/or analyzed during the current study are available from the corresponding author on reasonable request.

\section{Competing interests}

The authors declare that they have no competing interests.

\section{Funding}

Not applicable

\section{Authors' contribution}

TK was the primary researcher, conceived the study, designed, participated in data collection, conducted data analysis, drafted and finalized the manuscript for publication. ZA, ET assisted in data collection and reviewed the initial and final drafts of the manuscript. DA interpreted the results, and reviewed the initial and final drafts of the manuscript and approved for publication. All authors read and approved the final manuscript.

\section{Acknowledgments}

Authors want to thank the staff in St. Paul's Hospital Millennium Medical College, Addis Ababa, Ethiopia for their kind support and advice in this study. In addition, the authors are grateful to the study participants for their voluntary participation.

\section{References}

\section{References}

1. Gozdowska J, Czerwińska M, Młynarczyk G, Kwiatkowski A, Chmura A, Durlik M. Urinary tract infections in kidney transplant recipients hospitalized at a transplantation and nephrology ward: 1-year follow-up. Transplant Proc. 2016; 48(5): 1580-1589.

2. Parasuraman R, Julian K. Urinary tract infections in solid organ transplantation.

Am J Transplant. 2013; 13 (s4): 327-336.

3. Fiorentino M, Pesce F, Schena A, Simone S, Castellano G and Gesualdo L. Updates on urinary tract infections in kidney transplantation. J Nephrol. 2019; 1-11.

4. Fontser S, Chacón $\mathrm{N}$ and Cordero. Review of bacterial urinary tract infection in kidney transplant recipients: incidence, risk factors and impact on the graft survival.

Int J Transplant Res Med. 2017; 3(1): 4045-10026.

5. Vidal E, Torre-Cisneros J, Blanes M, Montejo M, Cervera C, Aguado JM, et al. Bacterial urinary tract infection after solid organ transplantation in the RESITRA cohort. Transp/ Infect Dis. 2012; 14(6):595-603

6. Origüen J, López-Medrano F, Fernández-Ruiz M, Polanco N, Gutiérrez E, González E, et al. Should asymptomatic bacteriuria be systematically treated in kidney transplant recipients? Results from a randomized controlled trial. Am J Transplant. 2016;16(10):2943-2953

7. Khosravi AD, Montazeri EA, Ghorbani A, Parhizgari N. Bacterial urinary tract infection in renal transplant recipients and their antibiotic resistance pattern: A four-year study. 
8. Säemann M, Hörl WH. Urinary tract infection in renal transplant recipients.

Eur J Clin Invest.2008; 38:58-65.

9. Goldman JD, Julian K and AST Infectious Diseases Community of Practice. Urinary tract infections in solid organ transplant recipients: Guidelines from the American Society of Transplantation Infectious Diseases Community of Practice. Clin Transplant. 2019; e13507

10. Hollyer lan and Michael G Ison. The challenge of urinary tract infections in renal transplant recipients. Transp/ Infect Dis. 2018; 20(2): e12828

11. Chuang P, Parikh CR, Langone A. Urinary tract infections after renal transplantation: a retrospective review at two US transplant centers. Clin Transplant. 2005; 19 (2):230-235.

12. Ariza-Heredia EJ, Beam E, Lesnick TG, Cosio F, Kremers WK, Razonable R. Impact of urinary tract infection on allograft function after kidney transplantation. Clin Transplant. 2014; 28 (6):683-690.

13. Julien Coussement and Daniel Abramowicz. Should we treat asymptomatic bacteriuria after renal transplantation? Nephrol Dial Transplant. 2014; 29(2): 260-262.

14. Gondos AS, Al-Moyed KA, Al-Robasi AB, Al-Shamahy HA, Alyousefi NA. Urinary tract infection among renal transplant recipients in Yemen. PloS ONE. 2015; 10(12):e0144266.

15. Nicolle LE, Bradley S, Colgan R, Rice JC, Schaeffer A, Hooton TM. Infectious Diseases Society of America guidelines for the diagnosis and treatment of asymptomatic bacteriuria in adults.

Clin Infect Dis. 2005; 643-54.

16. Leber M (2018) Clinical microbiology procedures hand book. Fourth ed. ASM: 2018.

17. Performance Standards for Antimicrobial Susceptibility Testing. $28^{\text {th }}$ ed. CLSI supplement M100. Wayne, PA: Clinical and Laboratory Standards Institute; 2018.

18. Shahid Husain and Coleman Rotstein. Infections in solid organ transplant recipients.

Clin Infect Dis. 2018; 4(2):231-242.

19. Lorenz EC, Cosio FG. The impact of urinary tract infections in renal transplant recipients.

Kidney Int. 2010; 78(8):719-721.

20. De Souza RM, Olsburgh J. Urinary tract infection in the renal transplant patient.

Nat Clin Pract Nephrol. 2008; 4(5):252-264

21. Fiorante S, Lopez-Medrano F, Lizasoain M, Lalueza A, Juan RS, Andrés A, et al. Systematic screening and treatment of asymptomatic bacteriuria in renal transplant recipients. Kidneylnt. 2010; 78(8):774-781.

22. Pelle G, Vimont S, Levy PP, Hertig A, Ouali N, Chassin C, et al. Acute pyelonephritis represents a risk factor impairing long-term kidney graft function.

Am J Transplant. 2007; 7(4):899-907.

23. Kotagiri P, Chembolli D, Ryan J, Hughes PD, Toussaint ND. Urinary tract infections in the first year post-kidney transplantation: potential benefits of treating asymptomatic bacteriuria.

Transplant Proc. 2017; 49(9): 2070-2075

24. Shams SF, Eidgahi ES, Lotfi Z, Khaledi A, Shakeri S, Sheikhi M, et al. Urinary tract infections in kidney transplant 1st year after transplantation. J Res Med Sci. 2017; 22(3):45-62.

25. Bispo A, Fernandes M, Toscano C, Marques T, Machado D, Weigert A. Urinary tract infections in a cohort of kidney transplant recipients. Acta Med Port. 2014; 27 (3):364-371. 
26. Alkatheri AM. Urinary tract infections in Saudi renal transplant recipients.

J Infect Dis Immun. 2013; 5(2):18-23

27. Sadeghi M, Daniel V, Naujokat C, Wiesel M, Hergesell O, Opelz G. Strong inflammatory cytokine response in male and strong antiinflammatory response in female kidney transplant recipients with urinary tract infection. Transp/ Int. 2005; 18(2):177-185.

28. Ciszek M, Paczek L, Bartlomiejczyk I, Mucha K. Urine cytokines profile in renal transplant patients with asymptomatic bacteriuria. Transplant Proc. 2006; 81(12):1653-1657.

29. Becerra BJ, Becerra MB, Safdar N. A nationwide assessment of the burden of urinary tract infection among renal transplant recipients. J Transplant. 2015; 20 (15):124-145.

30. Kumar A, Agarwal C, Hooda AK, Ojha A, Dhillon M, Hari Kumar KV. Profile of infections in renal transplant recipients from India. J Family Med Prim Care. 2016; 5(3):611-614.

31. Menegueti MG, Pereira MF, Bellissimo-Rodrigues F, Garcia TMP, Saber LTS, Nardim MEP, et al. Study of the risk factors related to acquisition of urinary tract infections in patients submitted to renal transplant. Rev Soc Bras Med Trop. $2015 ; 48(3): 285$.

32. Elkehili I, Kekli A, Zaak A, Salem Urinary tract infection in renal transplant recipients.

Arab J Urol. 2010; 3(2):53-55.

33. Ooms L, ljzermans J, Holt Voor , Betjes M, Vos M , Terkivatan T. Urinary tract infections after kidney transplantation: A risk factor analysis of 417 patients. Ann Transplant. 2017; 22:402-408

34. Veroux M, Giuffrida G, Corona D, Gagliano M, Scriffignano V, Vizcarra D, et al. Infective complications in renal allograft recipients: epidemiology and outcome. Transplant Proc.2008; 40(6):1873-1876

35. Valera B, Gentil MA, Cabello V, Fijo J, Cordero E, Cisneros JM. Epidemiology of urinary infections in renal transplant recipients. Transplant Proc. 2006; 38(8): 2414-2415

36. Papasotiriou M, Savvidaki E, Kalliakmani P, Papachristou E, Marangos M, Fokaefs E, et al. Predisposing factors to the development of urinary tract infections in renal transplant recipients and the impact on the long-term graft function.

Ren fail. 2011; 33(4):405

37. Flores-Mireles AL, Walker JN, Caparon M, Hultgren SJ. Urinary tract infections: epidemiology, mechanisms of infection and treatment options. Nature REV Microbiol. 2015; 13(5):269.

38. Abbott KC, Swanson SJ, Richter ER, Bohen EM, Agodoa LY, Peters TG, et al. Late urinary tract infection after renal transplantation in the United States.

Am J Kidney Dis. 2004; 44 (2):353-362.

39. Yuan X, Liu T,Wu D and Wan Q. Epidemiology, susceptibility, and risk factors for acquisition of MDR/XDR Gram-negative bacteria among kidney transplant recipients with urinary tract infections. Infect Drug Resist. 2018; 14(11):707-715.

40. Ndemera $\mathrm{H}$, Bhengu B. Factors contributing to kidney allograft loss and associated consequences among post -kidney transplant patients. HSJ. 2017; 11(3):1.

41. Bodro M, Sanclemente G, Lipperheide I, Allali M, Marco F, Bosch J, et al. Impact of urinary tract infections on short-term kidney graft outcome.

Clin Microbiol Infect. 2015; 21(12):1104.

42. Magiorakos AP, Srinivasan A, Carey RB, Carmeli Y, Falagas ME, Giske CG, et al. Multidrug-resistant, extensively drug-resistant and pan drug-resistant bacteria: an international expert proposal for interim standard definitions for acquired resistance. Clin Microbiol Infect. 2012; 18(3):268-281

43. Adamska Z, Karczewski M, Cichanska L. Bacterial infections in renal transplant recipients.

Transplant Proc. 2015; 47:1808-18012.

44. Ak O, Yildirim M, Kucuk HF, Gencer S, Demir T. Infections in renal transplant patients: risk factors and infectious agents. Transplant Proc. 2013; 45(3): 944-948.

Page $10 / 15$ 
45. Foxman B. Urinary tract infection syndromes: occurrence, recurrence, bacteriology, risk factors, and disease burden. Infect Dis Clin North Am. 2014; 28(1):1-3.

46. Pesce F, Martino M, Fiorentino M, Rollo T, Simone S, Gallo P, et al. Recurrent urinary tract infections in kidney transplant recipients during the first-year influence long-term graft function: a single-center retrospective cohort study. J Nephrol. 2019; 1-8.

47. Naik AS, Dharnidharka VR, Schnitzler MA, Brennan DC, Segev DL, Axelrod D, et al. Clinical and economic consequences of first-year urinary tract infections, sepsis and pneumonia in contemporary kidney transplantation practice.

Transp/ Int. 2016; 29(2): 241-252

48. Lim JH, Cho JH, Lee JH, Park YJ, Jin S, Park GY, et al. Risk factors for recurrent urinary tract infection in kidney transplant recipients.

Transplant Proc. 2013; 45(4): 1584-1589.

49. Markus Giessing. Urinary tract infection in renal transplantation. Arab J Urol. 2012; 10: 162-168.

50. Yacoub R, AkI NK. Urinary tract infections and asymptomatic bacteriuria in renal transplant J Glob Infect Dis. 2011; 3(4):383.

\section{Tables}

: Sociodemographic characteristics of study participants with and without UTI, St Paul's Hospital Millennium medical , Addis Ababa, Ethiopia.

\begin{tabular}{|c|c|c|c|c|c|c|}
\hline iables & Total (\%) & UTI no (\%) & No UTI no (\%) & Bivar & te analysis & P-value \\
\hline 3nder & & & & COR & $95 \% \mathrm{CI}$ & \\
\hline Tale & $42(56.8)$ & $5(11.9)$ & $37(88.1)$ & 0.848 & $0.57-11.31$ & 0.419 \\
\hline male & $32(43.2)$ & $6(18.75)$ & $26(81)$ & 2.09 & $1.04-8.45$ & 0.253 \\
\hline Age & & & & & & \\
\hline $8-34$ & $29(39.2)$ & $4(13.8)$ & $25(86.2)$ & 1.42 & $0.64-14.05$ & 0.338 \\
\hline $5-49$ & $31(41.9)$ & $6(19.3)$ & $25(80.6)$ & 3.67 & $2.89-20.07$ & 0.003 \\
\hline $0-64$ & $10(13.5)$ & $1(10)$ & $9(90)$ & 3 & $2.91-10.00$ & 0.914 \\
\hline Jve 64 & $4(5.4)$ & $0(0.0)$ & $4(100)$ & 0.88 & $0.58-3.27$ & 0.444 \\
\hline al status & & & & & & \\
\hline ingle & $23(31)$ & $6(26.1)$ & $17(74)$ & 5.64 & $0.73-13.22$ & 0.222 \\
\hline irried & $30(40.5)$ & $4(13.3)$ & $26(86.7)$ & 1.724 & $1.081-6.82$ & 0.391 \\
\hline rorced & $12(16.2)$ & $1(8.3)$ & $11(91.7)$ & 7 & $4.36-9.15$ & 0.284 \\
\hline lowed & $5(6.8)$ & $0(0.0)$ & $5(100)$ & 0.23 & $0.11-3.74$ & 0.058 \\
\hline Jower & $4(5.4)$ & $0(0.0)$ & $4(100)$ & 8.04 & $2.05-10.09$ & 0.701 \\
\hline ional leve & & & & & & \\
\hline udent & 11(14.9) & $2(18.2)$ & $10(91)$ & 1 & $0.37-4.12$ & 0.348 \\
\hline Jloma & $31(41)$ & $5(16)$ & $26(83.9)$ & 2.872 & $0.81-5.06$ & 0.579 \\
\hline gree & $13(17.6)$ & $2(15)$ & $11(84.6)$ & 4 & $2.01-6.19$ & 0.441 \\
\hline terate & $15(20)$ & $2(13)$ & 13(86.7) & 2.11 & $1.90-17.48$ & 0.990 \\
\hline e degree & $4(5.4)$ & $0(0.0)$ & $4(100)$ & 0.81 & $0.36-1.34$ & 0.007 \\
\hline
\end{tabular}

: Prevalence of UTI in related clinical variables of renal transplants recipients. 


\begin{tabular}{|c|c|c|c|c|c|c|}
\hline \multirow[b]{2}{*}{ Variables } & \multirow[b]{2}{*}{ Total (\%) } & \multirow[b]{2}{*}{ UTI no (\%) } & \multirow[b]{2}{*}{ No UTI no (\% ) } & \multicolumn{2}{|c|}{ Bivariate analysis } & \multirow[b]{2}{*}{ p-value } \\
\hline & & & & COR & $95 \% \mathrm{CI}$ & \\
\hline \multicolumn{7}{|c|}{ nce transplantation } \\
\hline $0-6$ months & $17(22.9)$ & $3(17.6)$ & $14(82.3)$ & 2.29 & $0.42-2.96$ & 0.391 \\
\hline 7-12 months & $19(25.7)$ & $4(21)$ & $15(79)$ & 2.57 & $1.09-11.03$ & 0.555 \\
\hline 3-24 months & $19(25.7)$ & $2(10.5)$ & $17(89.5)$ & 0.71 & $0.54-6.38$ & 0.081 \\
\hline$>24$ months & $19(25.7)$ & $2(10.5)$ & $17(98.5)$ & 1.23 & $0.98-7 / 11$ & 0.661 \\
\hline \multicolumn{7}{|c|}{ Insplant UTI history } \\
\hline Yes & $5(6.8)$ & $2(40)$ & $3(60)$ & 4.32 & $2.09-17.10$ & 0.010 \\
\hline No & $69(93.2)$ & $9(13)$ & $60(87)$ & 0.51 & $0.26-2.11$ & 0.997 \\
\hline \multicolumn{7}{|c|}{ the transplantation } \\
\hline Local & $54(73)$ & $9(16.7)$ & $45(83.3)$ & 4.01 & $0.18-19.06$ & 0.481 \\
\hline Abroad & $20(27)$ & $2(10)$ & $18(90)$ & 0.89 & $0.69-8.81$ & 0.671 \\
\hline \multicolumn{7}{|l|}{ onor's gender } \\
\hline Male & $40(54.1)$ & $5(12.5)$ & $35(87.5)$ & 3.1 & $2.19-3.70$ & 0.561 \\
\hline Female & $34(45.9)$ & $4(11.8)$ & $30(88.2)$ & 2.07 & $1.04-7.31$ & 0.549 \\
\hline \multicolumn{7}{|c|}{7 of Catheterization } \\
\hline Yes & $5(6.8)$ & $1(20)$ & $4(80)$ & 1.90 & $1.11-11.38$ & 0.001 \\
\hline No & $69(93.2)$ & $10(14.5)$ & $59(85.5)$ & 0.53 & $0.21-0.98$ & 0.941 \\
\hline \multicolumn{7}{|c|}{ donor category } \\
\hline emale to male & $17(23)$ & $2(11.8)$ & $15(88.2)$ & 0.23 & $0.10-1.93$ & 0.234 \\
\hline Tale to female & $22(29.7)$ & $5(22.7)$ & $17(72.3)$ & 1.09 & $1.07-13.03$ & 0.306 \\
\hline Male to male & $17(23)$ & $2(11.8)$ & $15(88.2)$ & 0.91 & $0.54-2.41$ & 0.773 \\
\hline male to female & $18(24.3)$ & $2(11.1)$ & $16(88.9)$ & 1 & $0.62-6.78$ & 0.009 \\
\hline
\end{tabular}

: Significant bacteriuria from urine culture of renal transplant recipients

\begin{tabular}{|c|c|c|c|c|c|}
\hline ignificant bacteriuria & \multicolumn{2}{|c|}{ Frequency(n) } & \multicolumn{3}{|c|}{ Percent (\%) } \\
\hline Yes & \multicolumn{2}{|c|}{11} & \multicolumn{3}{|c|}{14.9} \\
\hline No & \multicolumn{2}{|c|}{63} & \multicolumn{3}{|c|}{85.1} \\
\hline Total & & & \multirow{2}{*}{\multicolumn{3}{|c|}{100}} \\
\hline \multirow[t]{2}{*}{ nal transplant recipients } & \multicolumn{2}{|c|}{ Significant bacteriuria } & & & \\
\hline & Yes & No & Total & COR(95\%CI) & P-value \\
\hline Asymptomatic no (\%) & $8(22.2)$ & $28(77.8)$ & $\overline{36(48.7)}$ & & \\
\hline Symptomatic no (\%) & $3(7.9)$ & $35(92.1)$ & $38(51.3)$ & $1.01(0.547-3.829)$ & 0.847 \\
\hline Total no (\%) & $11(14.9)$ & $63(85.1)$ & $74(100)$ & & \\
\hline
\end{tabular}

4: Bacterial species isolated from asymptomatic and symptomatic UTI among renal transplant recipients, St Paul's ll Millennium medical college, Addis Ababa, Ethiopia. 


\begin{tabular}{|c|c|c|c|}
\hline icterial isolates & Asymptomatic RTX no (\%) & Symptomatic RTX no (\%) & Total (\%) \\
\hline Gram-negative & $\mathbf{5 ( 6 2 . 5 )}$ & $\mathbf{0 ( 0 . 0 )}$ & $\mathbf{5 ( 4 5 . 4 )}$ \\
\hline E.coli & $2(25)$ & $0(0.0)$ & $2(18.18)$ \\
\hline netobacter spp. & $2(25)$ & $0(0.0)$ & $2(18.18)$ \\
\hline P.mirabilis & $1(12.5)$ & $0(0.0)$ & $1(9.1)$ \\
\hline iram-positive & $\mathbf{3 ( 3 7 . 5 )}$ & $\mathbf{3 ( 9 9 . 9 )}$ & $\mathbf{6 ( 5 4 . 6 )}$ \\
\hline terococcus spp. & $1(12.5)$ & $1(33.3)$ & $2(18.18)$ \\
\hline CoNS & $1(12.5)$ & $1(33.3)$ & $2(18.18)$ \\
\hline S.aureus & $1(12.5)$ & $1(33.3)$ & $2(18.18)$ \\
\hline Total & $\mathbf{8 ( 7 2 . 7 )}$ & $\mathbf{3 ( 2 7 . 3 )}$ & $\mathbf{1 1 ( 1 0 0 )}$ \\
\hline
\end{tabular}

CoNS=Coagulase Negative Staphylococci

\section{5: Bacterial etiologic agents isolated from urine culture of renal transplants}

\begin{tabular}{c|c|c|}
\hline Bacterial isolates & Frequency(n) & Percent (\%) \\
\hline Gram-Negative & 5 & $\mathbf{4 5 . 4}$ \\
\hline E.coli & 2 & 18.2 \\
\hline Acinetobacter spp. & 2 & 18.2 \\
\hline P.mirabilis & 1 & 9.1 \\
\hline Gram-positive & 6 & 54.6 \\
\hline Enterococcus spp. & 2 & 18.2 \\
\hline CoNS & 2 & 18.2 \\
\hline S.aureus & 2 & 18.2 \\
\hline Total & 11 & $\mathbf{1 0 0}$ \\
\hline
\end{tabular}

: Antibacterial susceptibility patterns of Gram-positive bacterial isolates.

\begin{tabular}{|c|c|c|c|c|c|c|c|c|c|c|c|c|c|}
\hline \multirow{2}{*}{\multicolumn{3}{|c|}{ e Culture out put }} & \multicolumn{11}{|c|}{ Antibacterial agents tested } \\
\hline & & & VA & CTR & CHL & NIT & AMC & PEN & TET & SXT & ERY & CLN & $\mathrm{CN}$ \\
\hline rial isolates & Total & Pattern & no(\%) & no(\%) & no(\%) & no(\%) & no $(\%)$ & no(\%) & no(\%) & no(\%) & no $(\%)$ & no (\%) & no $(\%)$ \\
\hline $\begin{array}{l}\text { aureus } \\
(\mathrm{n}=2)\end{array}$ & 2 & $\begin{array}{l}\mathrm{R} \\
\mathrm{I} \\
\mathrm{S}\end{array}$ & $\begin{array}{c}0(0) \\
2(100 \\
0(0)\end{array}$ & $\begin{array}{c}2(100) \\
0(0) \\
0(0)\end{array}$ & $\mid \begin{array}{c}2(100) \\
0(0) \\
0(0)\end{array}$ & $\begin{array}{c}2(100) \\
0(0) \\
0(0)\end{array}$ & $\begin{array}{c}1(50) \\
0(0) \\
1(50)\end{array}$ & $\begin{array}{c}2(100 \\
0(0) \\
0(0)\end{array}$ & $\begin{array}{c}1(50) \\
0(0) \\
1(50\end{array}$ & $\begin{array}{c}1(50) \\
0(0) \\
1(50)\end{array}$ & $\begin{array}{c}0(0) \\
0(0) \\
2(100\end{array}$ & $\begin{array}{c}0(0) \\
0(0) \\
2(100)\end{array}$ & $\begin{array}{c}0(0) \\
0(0) \\
2(100)\end{array}$ \\
\hline $\begin{array}{l}\text { CoNS } \\
(n=2)\end{array}$ & 2 & $\begin{array}{l}\mathrm{R} \\
\mathrm{I} \\
\mathrm{S}\end{array}$ & $\begin{array}{c}1(50) \\
0(0) \\
1(50)\end{array}$ & $\begin{array}{c}1(50) \\
1(50) \\
0(0)\end{array}$ & $\mid \begin{array}{c}2(100) \\
0(0) \\
0(0)\end{array}$ & $\begin{array}{c}2(100) \\
0(0) \\
0(0)\end{array}$ & $\begin{array}{c}2(100 \\
0(0) \\
0(0)\end{array}$ & $\begin{array}{l}0(0) \\
1(50) \\
1(50)\end{array}$ & $\begin{array}{c}2(100 \\
0(0) \\
0(0)\end{array}$ & $\begin{array}{l}0(0) \\
1(50) \\
1(50)\end{array}$ & $\begin{array}{c}0(0) \\
2(100 \\
0(0)\end{array}$ & $\begin{array}{c}0(0) \\
0(0) \\
2(100)\end{array}$ & $\begin{array}{c}2(100) \\
0(0) \\
0(0)\end{array}$ \\
\hline $\begin{array}{l}\text { terococcus } \\
\text { pp. }(\mathrm{n}=2)\end{array}$ & 2 & $\begin{array}{l}\mathrm{R} \\
\mathrm{I} \\
\mathrm{S}\end{array}$ & $\begin{array}{c}0(0) \\
2(100 \\
0(0)\end{array}$ & $\begin{array}{c}2(100) \\
0(0) \\
0(0)\end{array}$ & $\begin{array}{c}0(0) \\
1(50) \\
1(50)\end{array}$ & $\begin{array}{c}0(0) \\
0(0) \\
2(100)\end{array}$ & $\begin{array}{c}2(100 \\
0(0) \\
0(0)\end{array}$ & $\begin{array}{c}1(50) \\
0(0) \\
1(50)\end{array}$ & $\begin{array}{c}1(50) \\
0(0) \\
1(50)\end{array}$ & $\begin{array}{c}2(100 \\
0(0) \\
0(0)\end{array}$ & $\begin{array}{c}2(100 \\
0(0) \\
0(0)\end{array}$ & $\begin{array}{c}2(100 \\
0(0) \\
0(0)\end{array}$ & $\begin{array}{c}2(100) \\
0(0) \\
0(0)\end{array}$ \\
\hline $\begin{array}{l}\text { Total } \\
(\mathrm{n}=6)\end{array}$ & 6 & $\begin{array}{l}\mathrm{R} \\
\mathrm{I} \\
\mathrm{S}\end{array}$ & $\begin{array}{l}1(17) \\
4(67) \\
1(17)\end{array}$ & $\begin{array}{c}5(83) \\
1(17) \\
0(0)\end{array}$ & $\begin{array}{l}4(67) \\
1(17) \\
1(17)\end{array}$ & $\begin{array}{c}4(67) \\
0(0) \\
2(33)\end{array}$ & $\begin{array}{c}5(83) \\
0(0) \\
1(17)\end{array}$ & $\begin{array}{l}3(50) \\
1(17) \\
2(33)\end{array}$ & \begin{tabular}{|c}
$4(67)$ \\
$0(0)$ \\
$2(33)$
\end{tabular} & $\begin{array}{l}3(50) \\
1(17) \\
2(33)\end{array}$ & $\begin{array}{l}2(33) \\
2(33) \\
2(33)\end{array}$ & $\begin{array}{c}2(33) \\
0(0) \\
4(67)\end{array}$ & $\begin{array}{c}4(67) \\
0(0) \\
2(33)\end{array}$ \\
\hline
\end{tabular}

viations: $\quad \mathbf{R}=$ Resistant $\quad \mathrm{S}=$ Sensitive $\mathbf{I}=$ Intermediate, $\mathbf{A M C}=$ Amoxicillin Clavulanate acid, CTR=Ceftriaxone, Chloramphenicol, CLN=Clindamycin, ERY=Erythromycin, CN=Gentamicin, NIT = Nitrofurantoin, TET=Tetracycline, Trimethoprim-Sulfamethoxazole, VA= Vancomycin, PEN = Penicillin 
7: Antibacterial susceptibility patterns of Gram-negative bacteria isolates.

\begin{tabular}{|c|c|c|c|c|c|c|c|c|c|c|c|c|c|}
\hline \multirow{2}{*}{\multicolumn{3}{|c|}{ llture out put }} & \multicolumn{11}{|c|}{ Antibacterial agents tested } \\
\hline & & & CIP & TET & CN & AMC & $\mathrm{CHL}$ & NIT & SXT & CPM & CTR & MEM & DC \\
\hline 1 & Total & Pattern & $\begin{array}{l}\text { no } \\
(\%)\end{array}$ & no $(\%$ & no(\%) & no(\% & no $(\%$ & no(\%) & no $(\%$ & no $(\%$ & no $(\%$ & no(\%) & no $(\%$ \\
\hline$\iota=2)$ & 2 & $\begin{array}{l}\mathrm{R} \\
\mathrm{I} \\
\mathrm{S}\end{array}$ & $\begin{array}{c}2(100 \\
0(0) \\
0(0)\end{array}$ & $\begin{array}{c}1(50 \\
0(0) \\
1(50)\end{array}$ & $\begin{array}{c}0(0) \\
0(0) \\
2(100\end{array}$ & $\begin{array}{c}1(50) \\
1(50) \\
0(0)\end{array}$ & $\begin{array}{c}2(100 \\
0(0) \\
0(0)\end{array}$ & $\begin{array}{c}2(100 \\
0(0) \\
0(0)\end{array}$ & $\begin{array}{c}2(100 \\
0(0) \\
0(0)\end{array}$ & $\begin{array}{c}2(100 \\
0(0) \\
0(0)\end{array}$ & $\begin{array}{c}2(100 \\
0(0) \\
0(0)\end{array}$ & $\begin{array}{c}0(0) \\
2(100) \\
0(0)\end{array}$ & $\begin{array}{c}1(50) \\
0(0) \\
1(50)\end{array}$ \\
\hline $\begin{array}{l}\text { acter } \\
=2\end{array}$ & 2 & $\begin{array}{l}\text { R } \\
\mathrm{I} \\
\mathrm{S}\end{array}$ & $\begin{array}{c}2(100 \\
0(0 \\
0(0)\end{array}$ & $\begin{array}{c}0(0) \\
0(0) \\
2(100\end{array}$ & $\begin{array}{c}0(0) \\
0(0) \\
2(100\end{array}$ & $\begin{array}{c}2(100 \\
0(0 \\
0(0\end{array}$ & $\begin{array}{r}2(1000(0) \\
0(0)\end{array}$ & $\begin{array}{c}2(100 \\
0(0) \\
0(0)\end{array}$ & $\begin{array}{l}2(100 \\
0(00) \\
1(50)\end{array}$ & $\begin{array}{l}1(50) \\
0(0) \\
1(50)\end{array}$ & $\begin{array}{c}2(100 \\
0(0) \\
0(0)\end{array}$ & $\begin{array}{c}1(50) \\
1(50) \\
0(0)\end{array}$ & $\begin{array}{c}0(0) \\
0(0) \\
2(100\end{array}$ \\
\hline bilis & 1 & $\begin{array}{l}\mathrm{R} \\
\mathrm{I} \\
\mathrm{S}\end{array}$ & $\begin{array}{c}0(0) \\
0(0) \\
1(100\end{array}$ & $\begin{array}{c}1(100 \\
0(0) \\
0(0)\end{array}$ & $\begin{array}{l}0(0) \\
0(0) \\
1(10\end{array}$ & $\begin{array}{c}0(0) \\
0(0 \\
(100\end{array}$ & $\begin{array}{c}0(0) \\
1(00) \\
0(0)\end{array}$ & $\begin{array}{c}1(100 \\
0(0) \\
0(0)\end{array}$ & $\begin{array}{r}0(0) \\
1(100 \\
0(0)\end{array}$ & $\begin{array}{c}0(0) \\
0(0 \\
1(100\end{array}$ & $\begin{array}{c}0(0) \\
0(0) \\
1(100\end{array}$ & $\begin{array}{c}0(0) \\
0(0) \\
1(100\end{array}$ & $\begin{array}{l}1(100 \\
0(0) \\
0(0)\end{array}$ \\
\hline $1=5)$ & 5 & $\begin{array}{l}\mathrm{R} \\
\mathrm{I} \\
\mathrm{S}\end{array}$ & $\begin{array}{c}4(80) \\
0(0) \\
1(20)\end{array}$ & $\begin{array}{c}2(40) \\
0(0) \\
3(60)\end{array}$ & $\begin{array}{c}0(0) \\
0(0) \\
5(100\end{array}$ & $\begin{array}{l}3(60) \\
1(20) \\
1(20)\end{array}$ & $\begin{array}{c}4(80) 1(20) \\
0(0)\end{array}$ & $\begin{array}{c}5(100 \\
0(0) \\
0(0)\end{array}$ & $\begin{array}{c}4(80) \\
1(20) \\
0(0)\end{array}$ & $\begin{array}{c}3(60) \\
0(0) \\
2(40)\end{array}$ & $\begin{array}{r}4(80) \\
0(0) \\
1(20)\end{array}$ & $\begin{array}{l}1(20) \\
3(60) \\
1(20)\end{array}$ & $\begin{array}{c}2(40) \\
0(0) \\
3(60)\end{array}$ \\
\hline
\end{tabular}

iations: $\quad \mathbf{R}=$ Resistant, $\mathbf{S}=$ Sensitive, $\mathbf{I}=$ Intermediate, $\mathbf{A M C}=$ Amoxicillin-Clavulanate acid, 'efepime,CTR=Ceftriaxone, $\mathbf{C H L}=$ Chloramphenicol, $\mathbf{C I P}=$ Ciprofloxacin, $\mathbf{C N}=$ Gentamicin , $\mathbf{M E R}=$ Meropenem, itrofurantoin, TET=Tetracycline, SXT=Trimethoprim-Sulfamethoxazole, $\mathbf{D C}=$ Doxycycline.

8: Multidrug resistance patterns of bacteria isolated from renal allografts.

\begin{tabular}{|l|c|l|l|l|l|l|l|}
\hline cterial isolates & Total (\%) & \multicolumn{7}{|c|}{ Antibacterial patterns } \\
\cline { 3 - 8 } & & $\mathbf{R}_{\mathbf{0}}$ & $\mathbf{R}_{\mathbf{1}}$ & $\mathbf{R}_{\mathbf{2}}$ & $\mathbf{R}_{\mathbf{3}}$ & $\mathbf{R}_{\mathbf{4}}$ & $\mathbf{Z}_{\mathbf{5}}$ \\
\hline im-negative & $\mathbf{5 ( 4 5 . 4 )}$ & $\mathbf{0 ( 0 . 0 )}$ & $\mathbf{0 ( 0 . 0 )}$ & $\mathbf{0 ( 0 . 0 )}$ & $\mathbf{2 ( 4 0 )}$ & $\mathbf{1 ( 2 0 )}$ & $\mathbf{2 ( 4 0 )}$ \\
\hline E.coli & $2(40)$ & $0(0.0)$ & $0(0.0)$ & $0(0.0)$ & $1(50)$ & $0(0.0)$ & $1(50)$ \\
\hline etobacter spp. & $2(40)$ & $0(0.0)$ & $0(0.0)$ & $0(0.0)$ & $0(0.0)$ & $1(50)$ & $1(50)$ \\
\hline P.mirabilis & $1(20)$ & $0(0.0)$ & $0(0.0)$ & $(0.0)$ & $1(100)$ & $0(0.0)$ & $0(0.0)$ \\
\hline am-positive & $\mathbf{6 ( 5 4 . 6 )}$ & $\mathbf{0 ( 0 . 0 )}$ & $\mathbf{1 ( 1 6 . 7 )}$ & $\mathbf{1 ( 1 6 . 7 )}$ & $\mathbf{0 ( 0 . 0 )}$ & $\mathbf{3 ( 5 0 )}$ & $\mathbf{1 ( 1 6 . 7 )}$ \\
\hline S.aureus & $2(33.33)$ & $0(0.0)$ & $0(0.0)$ & $0(0.0)$ & $0(0.0)$ & $2(100)$ & $0(0.0)$ \\
\hline CoNS & $2(33.33)$ & $0(0.0)$ & $1(50)$ & $0(0.0)$ & $0(0.0)$ & $1(50)$ & $0(0.0)$ \\
\hline rococcus spp. & $2(33.33)$ & $0(0.0)$ & $0(0.0)$ & $1(50)$ & $0(0.0)$ & $0(0.0)$ & $1(50)$ \\
\hline Total & $\mathbf{1 1 ( 1 0 0 )}$ & $\mathbf{0 ( 0 . 0 )}$ & $\mathbf{1 ( 9 . 1 )}$ & $\mathbf{1 ( 9 . 1 )}$ & $\mathbf{2 ( 1 8 . 2 )}$ & $\mathbf{4 ( 3 6 . 4 )}$ & $\mathbf{3 ( 2 7 . 3 )}$ \\
\hline
\end{tabular}

Jo antibiotic resistance, $\mathbf{R}_{\mathbf{1}}=$ Resistance to one, $\mathbf{R}_{\mathbf{2}}=$ Resistance to two, $\mathbf{R}_{\mathbf{3}}=$ Resistance to three, $\mathbf{R}_{\mathbf{4}^{-}}=$Resistance to four, :resistance to five and more drugs.

9: Multivariate risk factor analysis among post renal transplantation UTI. 


\begin{tabular}{|c|c|c|c|c|c|}
\hline $\mathbf{x}$ factor & \multicolumn{2}{|c|}{ Significant bacteriuria } & \multirow{2}{*}{ AOR } & \multirow{2}{*}{ 95\% CI } & \multirow{2}{*}{ P-value } \\
\cline { 1 - 3 } Age(years) & Yes no (\%) & No no (\%) & & & \\
\hline $18-34(\mathrm{n}=29)$ & $4(13.8)$ & $25(86.2)$ & 1 & 1 & \\
\hline $35-49(\mathrm{n}=31)$ & $6(19.3)$ & $25(80.6)$ & 2.61 & $2.06-18.91$ & $<0.001$ \\
\hline $50-64(\mathrm{n}=10)$ & $1(10)$ & $9(90)$ & 1.531 & $0.341-3.271$ & 0.245 \\
\hline$>64(\mathrm{n}=4)$ & $0(0.0)$ & $4(100)$ & $\mathrm{N} / \mathrm{A}$ & $\mathrm{N} / \mathrm{A}$ & \\
\hline e-transplant UTI history & & & & & \\
\hline Yes(n=5) & $2((40)$ & $3(60)$ & 3.48 & $2.12-9.39$ & 0.02 \\
\hline No(n=69) & $9(13)$ & $60(87)$ & $\mathrm{N} / \mathrm{A}$ & $\mathrm{N} / \mathrm{A}$ & \\
\hline of previous catheterization & & & & & \\
\hline Yes(n=5) & $1(20)$ & $4(80)$ & 3.29 & $2.05-11.85$ & 0.003 \\
\hline No(n=69) & & & & & \\
\hline
\end{tabular}

AOR=Adjusted Odds Ratio, 95\% CI =95\% Confidence Interval \& N/A= Not Applicable. 